\title{
Treatment of gonorrhoea with cotrimoxazole, procaine penicillin alone, and procaine penicillin plus probenecid
}

\author{
P. RODIN AND A. D. SETH \\ From the Department of Venereal Diseases and the Venereal Diseases Reference Laboratory, \\ The London Hospital
}

Successful treatment of gonorrhoea with cotrimoxazole ${ }^{\star}$ has now been reported by several workers (Csonka and Knight, 1967; Schofield, Masterton, Moffett, and McGill, 1969; Carroll and Nicol, 1970; Arya, Pearson, Rao, and Blowers, 1970; Ullman, Niordson, and Zachariae, 1971). Wright and Grimble (1970), however, who gave one tablet four times a day for 5 days, observed a failure rate of 38 per cent. of the 86 men followed. They claimed that in 45 per cent. of the failures a carrier state resulted which was detected by routine examination of Gramstained smears in all cases after treatment; cultures were not taken to prove the identity of the organism. They went so far as to say that the use of this drug combination was not justified in the routine treatment of gonorrhoea.

The present trial was undertaken to see if the findings of Wright and Grimble (1970) could be confirmed, but routine cultures as well as smears were employed both at the patient's initial attendance and at followup visits. Gonococcal isolates were confirmed by fermentation tests. As the results of routine treatment with single intramuscular injections of 1.2 mega units procaine penicillin had given less satisfactory results recently, the opportunity was taken to assess the effect of adding probenecid to this regime.

\section{Material and methods}

376 men suffering from acute gonococcal urethritis were allocated to five different treatment groups in random fashion. Habitual defaulters and those unable to attend for regular follow-up were excluded. Initial cultures were positive in approximately 90 per cent. of the patients. Three different methods of giving the same daily dosage of cotrimoxazole were used to see if this would influence the response. Thus Carroll and Nicol (1970) gave their patients four tablets in a single dose daily for 5 days, but Wright and Grimble gave one tablet four times daily for

Received for publication June 16,1972

^Bactrim-Roche and Septrin-Burroughs Wellcome. Each tablet contains $400 \mathrm{mg}$. sulphamethoxazole and $80 \mathrm{mg}$. trimethoprim.
5 days. Furthermore, the manufacturers recommend that a daily dosage of four tablets be given as two tablets twice daily.

\section{TREATMENT SCHEDULES}

These were as follows:

(1) Four tablets of cotrimoxazole in a single dose daily for 5 days ( 50 patients). The first dose was given in the clinic at the time of diagnosis, the second when the patient was seen again the next day, and the remaining three doses were given to the patient to take at home each morning.

(2) One tablet of cotrimoxazole four times daily for 5 days (51 patients).

(3) Two tablets of cotrimoxazole twice daily for 5 days (54 patients).

(4) $1.2 \mathrm{~m} . u$. procaine penicillin intramuscularly (110 patients).

(5) $1.2 \mathrm{~m}$.u. procaine penicillin intramuscularly plus $2 \mathrm{~g}$. probenecid by mouth given at the same time (111 patients).

\section{AGE AND RACE}

The age distribution was similar in each group and ranged from 15 to 51 years, the majority being between 20 and 34 years.

The various nationalities (Table I, overleaf) were also similarly distributed for the three cotrimoxazole groups and the two penicillin groups.

\section{FOLLOW-UP TESTS}

Patients in Group 1 had follow-up smears and cultures of urethral material taken on the 2nd, 7th, and 14th days after the treatment was started. In the other four groups smears and cultures were taken on the 3rd, 7th, and 14th days after treatment was started. All patients were asked to attend again 2 weeks later and those that did had similar tests. At every visit smears and cultures were taken whether there was obvious discharge or not. All the smears were examined by one of the authors (P.R.).

\section{SENSITIVITY TESTS}

Penicillin sensitivities were determined by an agar plate dilution method and the minimum inhibitory concentrations (MICs) reported. Initial screening was done using plates containing $0.06 \mu \mathrm{g}$. penicillin per $\mathrm{ml}$. and further 
TABLE I Nationalities of patients in each treatment group

\begin{tabular}{|c|c|c|c|c|c|}
\hline \multirow[b]{2}{*}{ Treatment group } & & \multicolumn{4}{|l|}{ Nationality } \\
\hline & & $\begin{array}{l}\text { United Kingdom } \\
\text { and Eire }\end{array}$ & Caribbean & Other & Total \\
\hline Cotrimoxazole & $\begin{array}{l}\text { (1) Single daily dose } \\
\text { (2) } 1 \text { tablet four times daily } \\
\text { (3) } 2 \text { tablets twice daily }\end{array}$ & $\begin{array}{l}23 \\
22 \\
24\end{array}$ & $\begin{array}{l}15 \\
15 \\
18\end{array}$ & $\begin{array}{l}12 \\
14 \\
12\end{array}$ & $\begin{array}{l}50 \\
51 \\
54\end{array}$ \\
\hline Penicillin & $\begin{array}{l}\text { (4) Procaine penicillin } \\
\text { (5) Procaine penicillin plus } \\
\text { probenecid }\end{array}$ & $\begin{array}{l}49 \\
48\end{array}$ & 42 & 19 & 110 \\
\hline
\end{tabular}

testing was done with higher concentrations if the organism was insensitive at this level. Sensitivity tests to cotrimoxazole were made by a disc diffusion method derived from that of Stokes (1968). Discs containing $23.75 \mu \mathrm{g}$. sulphamethoxazole and $1.25 \mu \mathrm{g}$. trimethoprim were used (this ratio corresponds roughly with that produced in the blood by the tablets of cotrimoxazolesee Garrod, 1969). Results were reported as sensitive, moderately sensitive, or resistant according to the criteria of Stokes (1968), except that she called intermediate stains moderately resistant rather than moderately sensitive. Streptomycin, tetracycline, and kanamycin sensitivities were tested by a similar method to that used for cotrimoxazole. For the disc sensitivity tests the Oxford staphylococcus (NCTC 6571) was used as the reference organism.

\section{Results}

\section{Cotrimoxazole}

Table II shows the frequency of recurrences in the three groups together with the incidence of subsequent non-gonococcal urethritis. There were seven recurrences in the first and two in the second week, giving an overall failure rate in this period of 6.7 per cent. of the 134 patients followed. In view of the 5 days required for completion of treatment, treatment failure was first diagnosed at the second visit seven days after treatment was started. Of the seven failures diagnosed at this time, six had positive smears and cultures and one a positive smear only.
Four of these seven were positive at the 3-day visit, one had a negative smear and culture then, and two did not attend at 3 days. Of the two recurrences in the second week, one was negative at the 3rd and 7th days and the other first attended 12 days after the start of treatment. Both had a positive culture as well as smear.

Three of the patients who were not cured by the one tablet four times daily schedule admitted that they did not take the tablets correctly. One who was not cured by the two tablets twice daily schedule also took the tablets incorrectly.

No evidence of a carrier state as described by Wright and Grimble (1970) was found. About twothirds of the patients were seen 2 weeks after treatment was started and only two further possible failures were detected in the second week (smears and cultures positive in both). Eighty were seen for longer periods and seven had recurrences; six occurred a month or longer after the original treatment started; all admitted further sexual contact and were almost certainly re-infected.

Among those in the first group who were seen the day after treatment started, Gram-negative diplococci were seen in smears in fifteen. These were extracellular only in nine (culture positive in one) and intracellular in six (cultures positive in five). One other patient had a negative smear but positive culture. Three of the fifteen defaulted, but the remainder had negative tests at the next visit.

TABLE II Results of treatment with cotrimoxazole for 5 days

\begin{tabular}{|c|c|c|c|c|c|c|c|c|}
\hline \multirow{3}{*}{ Treatment group } & \multirow{3}{*}{ No. treated } & \multirow{3}{*}{ No. followed } & \multicolumn{4}{|c|}{ Recurrences } & \multirow{2}{*}{\multicolumn{2}{|c|}{$\begin{array}{l}\text { Subsequent } \\
\text { Non-gonococcal } \\
\text { urethritis }\end{array}$}} \\
\hline & & & \multicolumn{2}{|c|}{ In first week } & \multicolumn{2}{|c|}{ In second week } & & \\
\hline & & & No. & per cent ${ }^{\mathrm{a}}$ & No. & per cent $t^{\mathrm{a}}$ & No. & per cent $t^{\mathrm{a}}$ \\
\hline $\begin{array}{l}\text { Single daily dose } \\
\text { One tablet four times daily } \\
\text { Two tablets twice daily }\end{array}$ & $\begin{array}{l}50 \\
51 \\
54\end{array}$ & $\begin{array}{l}43 \\
42 \\
49\end{array}$ & $\begin{array}{l}0 \\
4 \\
3\end{array}$ & $\begin{array}{r}0 \\
11 \cdot 9 \\
6 \cdot 1\end{array}$ & $\begin{array}{l}0 \\
1 \\
1\end{array}$ & $\begin{array}{l}0 \\
2 \cdot 4 \\
2 \cdot 0\end{array}$ & $\begin{array}{l}15 \\
13 \\
17\end{array}$ & $\begin{array}{l}34 \cdot 9 \\
31 \\
34 \cdot 7\end{array}$ \\
\hline Total & 155 & 134 & 7 & $5 \cdot 2$ & 2 & 1.5 & 45 & $33 \cdot 6$ \\
\hline
\end{tabular}

aPercentage of those followed 
Of those in the other two groups who were first seen 3 days after treatment was started, extracellular Gram-negative diplococci were seen in six (cultures negative in all) and intracellular in six (cultures positive in five). Four of the five patients who had positive cultures at 3 days were treatment failures at 7 days; the other defaulted.

Of the ten patients in Groups 2 and 3 who defaulted after examination on the 3rd day, only one had positive tests at the time of default, so that the results are unlikely to be favourably biased by this. The four other defaulters in these two groups did not attend at all after treatment was started.

One patient developed a rash but no other sideeffects were observed.

\section{Penicillin}

Table III shows the number of recurrences in the two groups treated with penicillin. Classing all recurrences within 2 weeks of treatment as failures, the failure rate was 13.7 per cent. for procaine penicillin alone and 1.9 per cent. for procaine penicillin plus probenecid. All except two of the treatment failures had positive cultures; three had positive cultures and negative smears.

The difficulty of deciding between treatment failure and re-infection is well known, but one of the patients treated with penicillin alone and found to have positive tests 7 days after the injection, admitted having had sexual intercourse with the as yet untreated original contact. Tests at his first visit, 3 days after treatment, had been negative and the organism was sensitive to $0.06 \mu \mathrm{g}$. penicillin per $\mathrm{ml}$. Three of the patients treated with penicillin alone and found to harbour gonococci in the 2nd week after treatment similarly admitted sexual intercourse with their original contacts, two of whom had proven but as yet untreated infection while the third did not attend. Two of these men had been infected with gonococci sensitive to $0.06 \mu \mathrm{g}$. penicillin per $\mathrm{ml}$. Thus, of the fourteen recurrences diagnosed in the first 2 weeks after treatment, four may have been re-infections.

The two patients who had recurrences after receiving procaine penicillin plus probenecid had both had negative tests at 3 days and each admitted further sexual intercourse with his original untreated contact. Both had been infected with gonococci sensitive to $0.06 \mu \mathrm{g}$. penicillin per ml., and could have been re-infected.

The penicillin sensitivities of the strains of gonococci from those who subsequently had recurrences are shown in Table IV.

\section{Overall results of sensitivity tests}

Sensitivity tests were carried out in 64 of the cases in the group given penicillin alone and 63 of those given penicillin plus probenecid. The results are shown in Table $\mathrm{V}$ (overleaf).

TABLE II I Results of treatment with $1.2 \mathrm{~m} . u$. procaine penicillin alone and with $2 \mathrm{~g}$. probenecid

\begin{tabular}{|c|c|c|c|c|c|c|c|c|}
\hline \multirow{3}{*}{ Treatment group } & \multirow{3}{*}{ No. treated } & \multirow{3}{*}{ No. followed } & \multicolumn{4}{|c|}{ Recurrences } & \multirow{2}{*}{\multicolumn{2}{|c|}{$\begin{array}{l}\text { Subsequent } \\
\text { Non-gonococcal } \\
\text { urethritis }\end{array}$}} \\
\hline & & & \multicolumn{2}{|c|}{ In first week } & \multicolumn{2}{|c|}{ In second week } & & \\
\hline & & & No. & per cent $t^{\mathrm{a}}$ & No. & per cent $t^{\mathrm{a}}$ & No. & per cent $t^{\mathrm{s}}$ \\
\hline Without probenecid & 110 & 102 & 9 & $8 \cdot 8$ & 5 & $4 \cdot 9$ & 27 & $26 \cdot 5$ \\
\hline With probenecid & 111 & 105 & 2 & 1.9 & 0 & 0 & 33 & $31 \cdot 4$ \\
\hline
\end{tabular}

apercentage of these followed

TABLE IV Penicillin sensitivities of gonococci among patients with recurrences

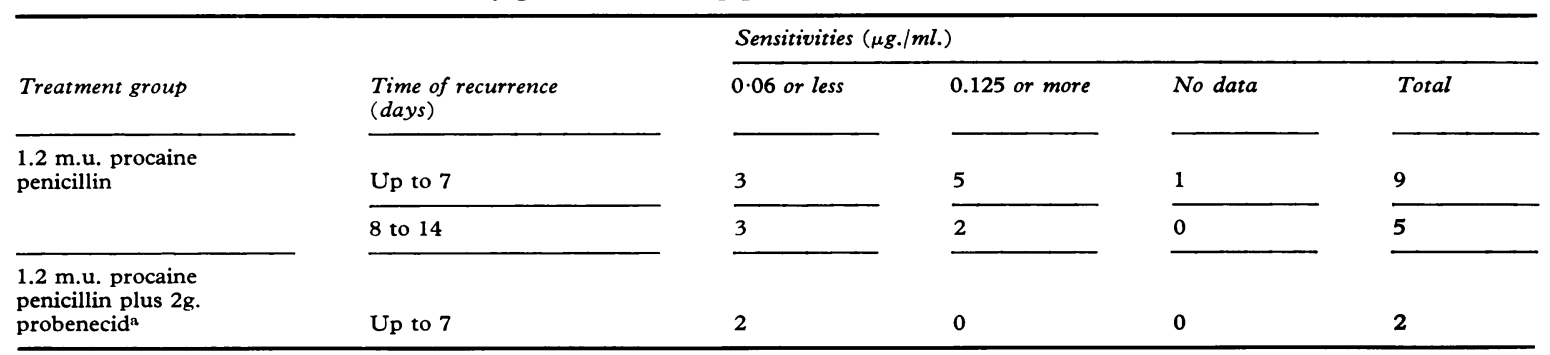

aThere were no recurrences between 8 and 14 days in this group. 
TABLE V Penicillin sensitivities in the two groups treated with penicillin

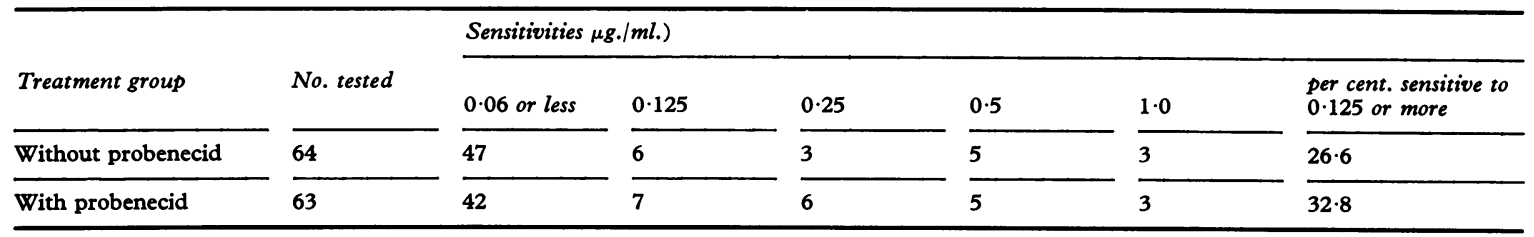

TABLE VI Sulphonamide and cotrimoxazole sensitivities in the three groups treated with cotrimoxazole

\begin{tabular}{|c|c|c|c|c|c|c|c|}
\hline \multirow{3}{*}{ Treatment group } & \multirow{3}{*}{ No. tested } & \multicolumn{6}{|c|}{ Sensitivities } \\
\hline & & \multicolumn{3}{|c|}{ Sulphonamide } & \multicolumn{3}{|c|}{ Cotrimoxazole } \\
\hline & & Sensitive & $\begin{array}{l}\text { Moderately } \\
\text { sensitive }\end{array}$ & Resistant & Sensitive & $\begin{array}{l}\text { Moderately } \\
\text { sensitive }\end{array}$ & Resistant \\
\hline $\begin{array}{l}\text { Single daily dose } \\
\text { One tablet four times daily } \\
\text { Two tablets twice daily }\end{array}$ & $\begin{array}{l}32 \\
37 \\
32\end{array}$ & $\begin{array}{l}21 \\
21 \\
19\end{array}$ & $\begin{array}{l}2 \\
5 \\
6\end{array}$ & $\begin{array}{r}9 \\
11 \\
7\end{array}$ & $\begin{array}{l}24 \\
25 \\
26\end{array}$ & $\begin{array}{r}8 \\
11 \\
6\end{array}$ & $\begin{array}{l}0 \\
1 \\
0\end{array}$ \\
\hline Total & 101 & 61 & 13 & 27 & 75 & 25 & 1 \\
\hline
\end{tabular}

aSulphafurazole

The percentage of less sensitive strains was a little higher in the group treated with penicillin plus probenecid, so that there was no bias in this regard to account for the better results in this group.

Sensitivity testing to sulphonamide alone and to cotrimoxazole was carried out in 32,37 , and 32 cases respectively of the three groups treated with cotrimoxazole. The results are shown in Table VI.

Tests were done on eight of the nine strains of gonococci from patients who subsequently proved to be treatment failures. One was resistant, three moderately sensitive, and four sensitive to cotrimoxazole, so that there was no real correlation between treatment failure and the results of testing in vitro apart from the one strain classed as resistant and which failed to respond.

The large number of strains found to be resistant to sulphonamides illustrates the synergistic effect of the sulphonamide-trimethoprim combination. Most of the strains classed as moderately sensitive to cotrimoxazole were resistant to the sulphonamide alone.

Altogether 228 strains isolated before treatment were subjected to sensitivity testing. Of these, 75 (32.9 per cent.) were sensitive to $0.125 \mu \mathrm{g}$. or more penicillin per $\mathrm{ml}$. Of these less sensitive strains 24 (32 per cent.) were classed as only moderately sensitive or resistant to cotrimoxazole compared with 29 ( 19 per cent.) of the 153 strains sensitive to $0.06 \mu \mathrm{g}$. or less penicillin per $\mathrm{ml}$. This difference is significant at the 0.05 level so that there is some evidence of cross-resistance.
Streptomycin sensitivities were tested only for those strains which showed reduced sensitivity to penicillin (MIC of $0.125 \mu \mathrm{g}$. per ml. or greater). Of 74 such strains, 63 were resistant to streptomycin. All 26 strains requiring $0.5 \mu \mathrm{g}$. or greater were resistant to streptomycin.

Tetracycline and kanamycin sensitivities were also tested only for those strains with reduced sensitivity to penicillin. All were found to be sensitive, except one strain which showed moderate resistance to kanamycin.

\section{Discussion}

There seems little doubt that cotrimoxazole is an effective treatment for gonorrhoea. It is difficult to account for the poor results obtained by Wright and Grimble (1970), but in the present trial the results obtained using the four times daily schedule (14.3 per cent. failures) were not as good as those obtained when the tablets were taken in a single dose once daily (no failures). The results with the twice daily dosage were intermediate. Several of the patients who failed to respond to the four times daily dosage admitted taking the tablets incorrectly and this might have partly accounted for the high failure rate reported by Wright and Grimble. Gram-stained smears were made at each follow-up visit in their series and they detected a high incidence of asymptomatic carriers among the treatment failures; cultures were not employed. In the present trial both smears and cultures were taken at each follow-up visit, but 
no evidence was found that treatment with cotrimoxazole had a particular tendency to produce a carrier state.

It is probable that patients taking their tablets once daily are more likely to take them correctly. Carroll and Nicol (1970) also used this regime with excellent results and it is recommended when patients are to be treated for gonorrhoea with a 5-day course of cotrimoxazole. Shortened courses of treatment have also proved effective (Arya and others, 1970; Ullman and others, 1971); these may well replace the 5-day course if the presumably increased danger of sulphonamide crystalluria with this more intensive treatment is found to be unimportant in practice.

In many parts of the world the efficacy of penicillin in the treatment of gonorrhoea has decreased owing to the development of strains of gonococci with reduced sensitivity to this drug. In the United Kingdom we have been relatively fortunate in that a satisfactory cure rate can still be obtained with moderate doses of penicillin. However, although at the London Hospital we have been able to use a single injection of $1.2 \mathrm{~m}$.u. procaine penicillin for the past 10 years, recently the results have not been quite so good. This is borne out by the findings in the present trial, in which the recurrence rate in the first 2 weeks was 13.7 per cent. $(8.8$ per cent. in the first week). As an alternative to increasing the dose of penicillin, probenecid can be added to the treatment regime and in the present series this resulted in a considerably better cure rate. Similar findings were reported by Cobbold, Spitzer, Morrison, and Willcox (1970). It does not seem to be necessary to give the probenecid at an interval before the penicillin injection, as in both our series and theirs good results were obtained by giving the two drugs together.

\section{Summary}

A 5-day course of cotrimoxazole was used to treat 155 men suffering from gonorrhoea and 134 were followed for at least 1 week. The same total dosage was given in three ways: four tablets in a single dose each day (50 patients), one tablet four times daily (51 patients), and two tablets twice daily (54 patients). The recurrence rates within 2 weeks of starting treatment among those followed were nil, 13.3, and $8 \cdot 1$ per cent. respectively and the recurrence rate for all three groups combined was 6.7 per cent.

Of 110 patients treated with 1.2 mega units procaine penicillin, 102 attended for follow-up; nine ( 8.8 per cent.) had recurrences in the first week and five (4.9 per cent.) in the second week. Of 111 patients treated with 1.2 mega units procaine penicillin plus $2 \mathrm{~g}$. probenecid, 105 were followed up; two ( 1.9 per cent.) had recurrences in the first week and none in the second week.

We are grateful to Messrs. Roche Products Limited for supplying us with the 'Bactrim' used in this trial. We would also like to thank Mr. Goldsmith and the rest of the nursing staff who contributed so greatly to the smooth running of the trial.

\section{References}

Arya, O. P., Pearson, C. H., Rao, S. K., and Blowers, R. (1970) Brit. F. vener. Dis., 46, 214

Carroll, B. R. T., and Nicol, C. S. (1970) Ibid., 46, 31

Cobbold, R. J. C., SPITZER, R. J., Morrison, G. D., and Willcox, R. R. (1970) Postgrad. med. F., 46, 142

CsoNKA, G. W., and KNIGHT, G. J. (1967) Brit. F. vener. Dis., 43, 161

Garrod, L. P. (1969) Postgrad. med. f., 45, Suppl. (Nov.), p.52

Schofield, C. B. S., MASTERTON, G., MOFFetT, M., and MCGILL, M. I. (1969) Ibid., 45, Suppl. (Nov.), p.81

STOKES, E. J. (1968) 'Clinical Bacteriology'. 3rd ed. Arnold, London

Ullman, S., Niordson, A.-M., and Zachariae, H (1971) Acta derm.-venereol. (Stockh.), 51, 394

WRIGHT, D. J. M., and GRIMBLE, A. S. (1970) Brit. F. vener. Dis., 46, 34

Traitement de la gonococcie par cotrimoxazole (triméthoprime-sulfaméthoxazole), pénicilline procaine seule et pénicilline-procaïne plus probénécide

\section{SOMMAIRE}

Un traitement de 5 jours par le cotrimoxazole fut employé chez 150 hommes atteints de gonococcie, dont 134 furent suivis au moins une semaine. La même dose totale fut donnée selon trois schémas: 4 comprimés en une seule dose chaque jour ( 50 malades), 1 comprimé quatre fois par jour chaque jour ( 51 malades) et 2 comprimés deux fois par jour (54 malades). Le taux de rechute dans les deux semaines après le début du traitement fut, chez les malades suivis, de $0 ; 13,3$ et 8,1 pour cent respectivement, et, pour l'ensemble des trois groupes, de 6,7 pour cent.

Parmi 110 malades traités avec 1,2 million d'unités de pénicilline-procaine, 102 se présentèrent au contrôle; neuf $(8,8$ pour cent) rechutèrent au cours de la première semaine et cinq (4,9 pour cent) au cours de la seconde. Parmi 111 malades traités avec 1,2 million d'unités de pénicilline-procaine plus $2 \mathrm{~g}$. de probénécide, 105 furent suivis; deux (1,9 pour cent) rechutèrent au cours de la première semaine et aucun au cours de la seconde. 